IRSTI 06.01 .33

https://doi.org/10.26577/CAJSH-2019-4-s4

\author{
${ }^{1}$ B.T. Yedilbayev, ${ }^{2}$ A.Sh. Shokanova, ${ }^{3}$ Zh.T. Kozhamkulova \\ ${ }^{1}$ Candidate technical of sciences, associate professor, Al-Farabi KazNU, \\ Almaty, RK b.t.yedilbayev@gmail.com, 0000-0002-3072-593X \\ ${ }^{2} \mathrm{PhD}$, Abai KazNPU, Almaty, RK \\ Shokanova@gmail.com, 55888225400 \\ ${ }^{3}$ Candidate economical of sciences, associate professor, Al-Farabi KazNU, Almaty, RK
}

\title{
ECONOMIC AND ECOLOGICAL MODEL OF THE LARGE CITIES DEVELOPMENT
}

\begin{abstract}
Developed economic - ecological model of modern large city on the example of Almaty, based on the main provisions of statistical theory, theories of logistics and the similarity of the General plan of development of Kazakhstan megapolis, the Strategy of transport development of Kazakhstan, programs to reduce the traffic load on the highways regulations of international and national importance, as well as on the basis of predictive decisions arising from the comprehensive consideration of the issues city transport road ecology (CTRE). It includes for the first time scientifically grounded ecological and economic indicators and daily ecological model of Almaty which were initial data for further researches and calculations.

However, this complex problem practically in all textbooks and manuals on ecology is considered factually, i.e. separately without interrelation, and questions of interrelation or mutual influence of emissions of motor transport in aggregate with infrastructure SRN (traffic lights, intersections, sidewalks, avenues, etc.) on environment aren't still considered in the world literature. Besides there are no data on distribution of exhaust gases (EG) of motor vehicle in the residential area near highways in any source. Therefore, even it is difficult to expert to define the main sources of pollution of urban air environment.
\end{abstract}

Key words: street road network, ecology, emissions, vehicle.

Introduction. Considering this question is necessary for the analysis of an ecological condition in the city and justification of prospects of its development. Thus known parameters were used, in the absence of those and existence of the similar, interconnected indicators of the Construction Norms and Regulations of Republic of Kazakhstan and Construction Norms and Regulations of the USSR (still used in Kazakhstan), and also our some lookahead decisions started with provisions of the static theory, the theory of logistics and similarity, the master plan of development of Almaty 20 years ago and now. They were accepted according to category of the population (children, school students, pensioners, and economically active part), nature of activity of inhabitants and a current state of a life of citizens etc.

According to the objectives of the main objects of research is Almaty. However, such a metropolis as a whole is impossible to study. It can be considered from the position of structural-element approach proposed by academician of NAS RK Balabekov O. S. and developed by his students. According to this theory, one characteristic element of an object with a known structure is investigated and, having determined the parametric relationship of a set of elements, it is possible to establish General laws of functioning of the object under consideration.

As you know, the main task of the state investment policy of our country is to create a favorable environment for the expansion of extra-budgetary sources of financing of capital investments and attracting private domestic and foreign investments on the basis of further improvement of the regulatory framework and state support for effective investment projects (Atici C., 2012:167-178).

There are several sectors of the economy: the development of natural resources, infrastructure, communications and information, which are essential for our country. The development of these industries will have an impact not only on economic growth, but also on the social sphere, as well as on the integration of Kazakhstan into the international community. These are capital-intensive industries, for the development of which both foreign capital and strict strategic control of the state are necessary (Birdsall N., 1993:137).

Prospects for the development of the country's economy are closely linked to the need to attract foreign direct investment. The formation of a favorable investment climate and the solution of problems to 
attract foreign direct investment in the priority sectors of the Republic of Kazakhstan, in turn, are associated with a set of economic, social, political, infrastructure and other aspects of economic development. Thus, at present, the Republic of Kazakhstan faces the task of attracting investments taking into account its own incentives and achievements of national goals (Dean, J.M. 1992:103).

Literature review. Studies on FDI have used several different proxies for the infrastructure variable (see Root, and Ahamed 1978y.; Nonnemberg and Cardoso 2002y.; Jaumotte 2004y. among others). Unfortunately, however, complete time series data on most of these proxies is not readily available for the period under study (1970-2007yy.). Consequently, this study followed Morisset (2000y.) and Nizar and Singleton (2001y.), among others and uses the number of telephone lines (landlines and mobile) per 1000 people in a country as a proxy for infrastructure. This has been reported to be a consistent and reliable measure of economic growth which has been extensively employed in the FDI literature (Asiedu, 2002.; Loree and Guisinger, 1995.; Khadaroo and Seetanah, 2003. Mutenyo, 2008.; Opolot, et al 2008.).

Also, Wheeler (2001y.) used data from three developing countries (China, Brazil and Mexico) with a high level of FDI to study its effect on pollution. In this case, he found that the level of FDI decreased the levels of pollution. For their part, Perkins and Neumayer (2008y.) verified the relationship between FDI and the efficiency in $\mathrm{CO} 2$ and $\mathrm{SO} 2$ emissions in 114 countries. The results proved that economies that started from a worse environmental situation improve their ecological efficiency faster when they adopted technologies and environmental policies similar to those of countries that started from a better situation, resulting in a convergence over time. Atici (2012y.) found, on the other hand, that the level of FDI had a negative and significant impact, so that they did not tend to increase pollution levels in the long term. On the other hand, the intensity of research and development activities has a great relevance on the relationship between the economic level and the level of pollution. On the one hand, there are direct effects of better efficiency on the reduction of pollution levels for a level of income. On the other hand, there is the effect of the greater benefit per unit of production, which decreases the energy intensity needed for production by each economic unit. Therefore, we assume that the greater the intensity of $R \& D$ activities, the lower the environmental impact of economic activities (Wheeler D., 2001:225).

In fact, Opolot et al (2008y.) contend that although the number of telephone lines may not be the best proxy for infrastructure, its significance nonetheless shows that infrastructure development does matter for FDI inflows to SSA. Accordingly, in this study, the assumption was that a country with a large number of telephone lines is more likely to have better roads, Internet access, and water/electricity supply, or in short better infrastructure. The model was specified just like Maria Delgado et al. (2000) and Balamurali et al (2004), the time subscripts are omitted for presentation simplicity.

Material and Methods. We have developed the following research plan:

1. Analysis of trends in the functioning, outflow and inflow of foreign direct investment in the priority sectors of the economy of the Republic of Kazakhstan.

2. The main countries investors in the Republic of Kazakhstan on the indicators.

In the country context, the largest FDI flows are from the following countries: The Netherlands - \$ 3.1 million., US \$ 2.3 million, Switzerland -1.2 million dollars, China - \$ 495.3 million, Russia $-\$$ 444.6 million., Belgium - \$ 646.4 million, France - \$415.6 million, Korea - \$ 246.8 million, UK - \$ 245.2 million (Sarsenov, 2017:4).

Table 1 - The number and structure of motor vehicle (for the beginning of year), one thousand units

\begin{tabular}{|c|c|c|c|c|c|c|c|c|}
\hline & $\mathbf{2 0 0 1}$ & $\mathbf{2 0 0 2}$ & $\mathbf{2 0 0 3}$ & $\mathbf{2 0 0 4}$ & $\mathbf{2 0 0 5}$ & $\mathbf{2 0 0 6}$ & $\mathbf{2 0 0 7} *$ & $\mathbf{2 0 1 5} * \boldsymbol{*}$ \\
\hline $\begin{array}{c}\text { Republic of } \\
\text { KazakhstanIncluding }\end{array}$ & 1349.5 & 1365.1 & 1471.5 & 1532.3 & 1752.6 & 1807.7 & \\
categories: & & & & & & & \\
A-automobile & 1057.8 & 1062.6 & 1148.7 & 1204.1 & & & \\
B-buses & 50.2 & 51.4 & 61.4 & 62.9 & 1405.3 & 1404.6 & $2000-2190$ & $2900-3100$ \\
L-lorries & 204.6 & 214.2 & 223.0 & 224.9 & 28.7 & 72.3 & \\
\hline Almaty & 236.1 & 206.0 & 262.2 & 235.9 & 289.3 & 340 & $410-420$ & $620-650$ \\
Including & & & & & & & \\
A & 201.1 & 165.7 & 218.2 & 199.5 & 254.8 & 287.3 & $344-353$ & $17-18$ \\
B & 7.9 & 6.8 & 11.9 & 9.6 & 8.1 & 11.6 & $49-50$ & \\
L & 23.2 & 30.6 & 29.0 & 23.0 & 26.4 & 41.1 & \\
\hline
\end{tabular}




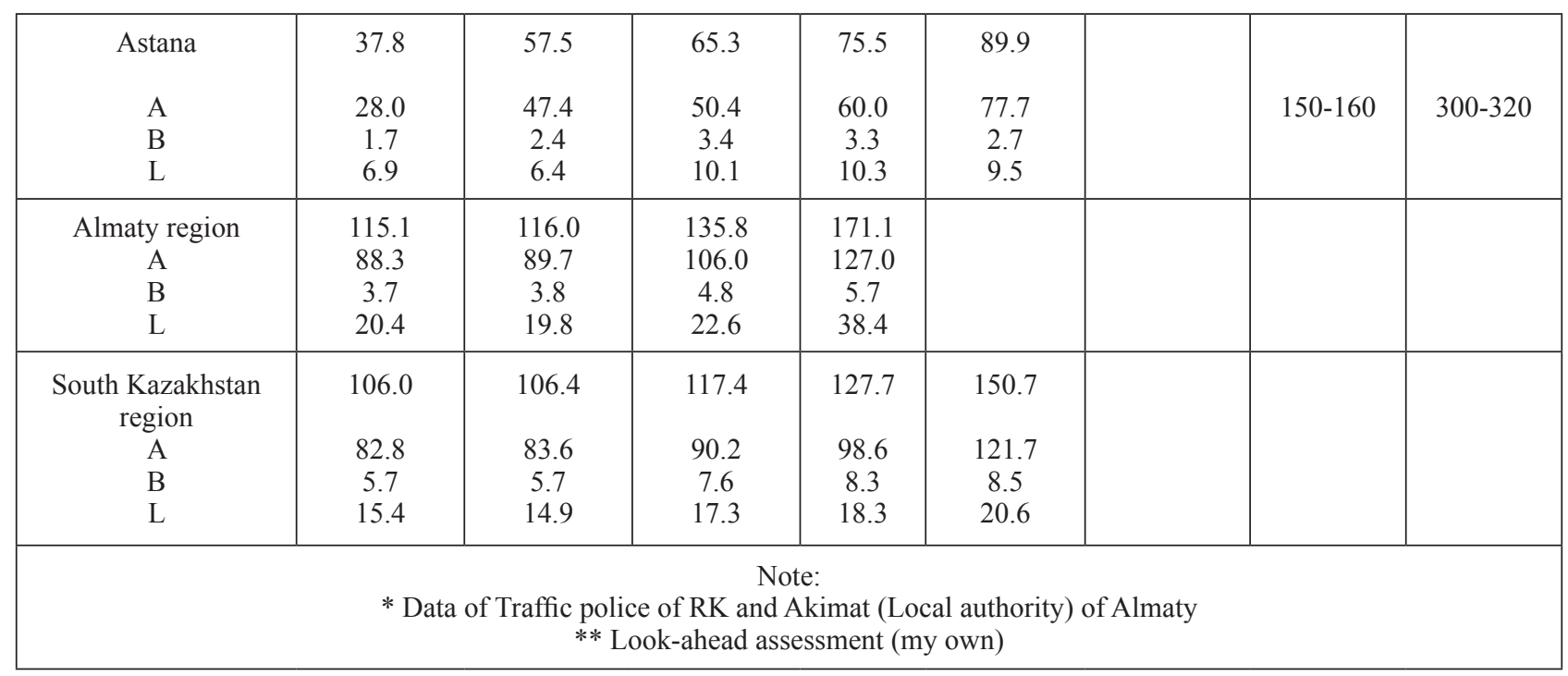

According to this methodology, the residential area of any city or locality should be considered along the chain: a residential building with pedestrian paths; a yard surrounded by residential buildings; a microdistrict (quarter) with access roads; a residential area; a city. Motor transport is studied in sequence: as a single car; cars moving in one lane after another or in a row on a multilane road in parallel, flow, and UDS - as part of the highway, limited by traffic lights (Table).

For example:

- while defining the population of Almaty it is noted that 1.3 million people constantly live in the city, 230 thousand students $(60-70 \%$ of them are nonresident as they are part-time students), 5060 thousand people come daily, 60-70 thousand people work temporarily (construction, trade) and live without a registration and also dynamics of birth rate and mortality on age were taken into consideration. Thus, daily population makes more than 1.5 million people. It is confirmed by the lookahead data of Almaty akimat;

- the number of motor vehicles is defined from table 1.5 and on the account that $97 \%$ of cars individual, according to the statistics theory only $2 / 3$ part of them (repair, because of high cost of gasoline public transport is cheaper, because of constant jams it is quicker and more usefully on foot, some families have 2-3 cars, the personal car and so forth), and from trucks and buses taking into account data on a passenger turnover and goods turnover only 85-90\% leave places of parking on the road. Thus, as it was noted in the previous section, 55-70 thousand motor vehicles drive daily in Almaty, more than 900 of them are nonresident buses. There are 1400 ambulance calls, 8-10 thousand taxi and private carriers daily in the city. Thus, we will receive that nearly 340 thousand units of cars are on highways of the city and they define intensity of movement of cars at rush hours and cause jams. This indicator is not predicted by Almaty akimat and is not defined;

- an assessment of conditional foodstuff carried out taking into account age categories, and also a way of life of the person. Almaty is the financial, educational and cultural center of Kazakhstan. Therefore its inhabitants generally carry out an inactive way of life. Daily consumption of products by children of preschool age and pupils of schools on the established norms makes 1000-1700g. The volume eaten by the adult person depending on his anthropometrical data and nature of labor activity is equal to $2,5-3,0 \mathrm{~kg}$. Calculations showed that for an average person in Almaty this indicator equals to $2.56 \mathrm{~kg}$;

- at determination of providing population with housing in Almaty started with conditions of environmental friendliness of houses (buildings), i.e. from comfort of stay in them which indicators are given in table 1: 
Table 1 - Indicators of comfortable staying of the person in a house

\begin{tabular}{|c|c|c|}
\hline \multirow{2}{*}{ Indicators } & \multicolumn{2}{|c|}{ Seasons of the year } \\
\hline & Cold & Warm \\
\hline $\begin{array}{c}\text { Air temperature, } \mathrm{C} \\
\text { Mobility of air, } \mathrm{m} / \mathrm{s} \\
\text { Humidity of air, \% } \\
\text { Differences of temperature, C: } \\
\text {-between a wall and air of rooms } \\
\text {-between a floor and air of rooms } \\
\text { Air volume on one person, } \mathrm{m} 3 / \text { people, at single air exchange: } \\
\text {-in living rooms and kitchens with electric stoves or } 2 \text { burners' gas stoves; } \\
\text {-with gas stoves with } 4 \text { burners; } \\
\text {-in lavatories } \\
\text { Concentration of easy ions in air, an ion } / \mathrm{cm}^{3} \\
\text { Concentration of ozone in air, } \mathrm{mkg} / \mathrm{m}^{3}\end{array}$ & $\begin{array}{l}20-22 \\
0.1-0.15 \\
30-45 \\
\\
2-3 \\
1.5 \\
60 \\
\\
90 \\
25 \\
1000-3000 \\
10-40\end{array}$ & $\begin{array}{l}22-25 \\
0.15-0.25 \\
30-60 \\
- \\
- \\
60 \\
90 \\
25 \\
1000-3000 \\
10-40\end{array}$ \\
\hline
\end{tabular}

However, the universal use of plastic windows in it which because of high density reduce mobility and an air exchange isn't considered. Therefore the air volume for one person in a living room is increased by us to $15-20 \%$.This transfer can be continued. Thus, developing ecological and economic indicators of Almaty (table 3) were based on strict scientifically reasonable methodology.
For the first time the developed ecological and economic indicators are basic data for research and calculation of an ecological situation of any settlement. There is no such group of data not only in Almaty, but also in other cities.

Scientific and practical value of the developed indicators will be confirmed in further researches. Here we will show the general model of an ecological condition in Almaty (table 3):

Table 3 - Ecological and economic indicators of Almaty for the beginning of 2007

\begin{tabular}{|c|c|c|c|c|c|}
\hline № & Indicators & $\begin{array}{l}\text { Values of } \\
\text { indicators }\end{array}$ & $\begin{array}{c}\text { Standard } \\
\text { (rational) } \\
\text { values }\end{array}$ & Excess & Deficiency \\
\hline $\begin{array}{l}1 \\
1.1 \\
1.2 \\
2 \\
2.1 \\
2.2 \\
2.3 \\
2.4 \\
3 \\
4 \\
5 \\
6 \\
7 \\
8 \\
9 \\
10 \\
10.1 \\
10.2 \\
10.3 \\
10.4 \\
10.5\end{array}$ & $\begin{array}{c}\text { Territory, thousand hectares, } \\
\text { The area of the planted trees and shrubs } \\
\text { territories } \\
\text { Total area of mirrors of water fund } \\
\text { Population, million people, including. } \\
\text { Economically active population: } \\
\text { Pupils } \\
\text { Students } \\
\text { Pensioners } \\
\text { Population density, thousand people/hec } \\
\text { Average providing the population with } \\
\text { housing, m }{ }^{2} / \text { person } \\
\text { Number of motor vehicles, thousand } \\
\text { Number of parking spaces (cars), } 1000 \\
\text { Density of highways with a firm covering } \\
\text { km/sq km } \\
\text { Transport density, units/hectares } \\
\text { Major maintenance of roads, km/year } \\
\text { Daily consumption: } \\
\text { Electricity, mln. kw/hour } \\
\text { heat, thousand Gcal } \\
\text { gas, million cubic meter } \\
\text { cold water, million cubic meter } \\
\text { bread, ton }\end{array}$ & $\begin{array}{c}31.9 \\
4.0 \\
1.12 \\
1.3(1.5) \\
0.650 \\
0.175 \\
0.230 \\
0.360 \\
40.7 \\
\\
22 \\
420(500) \\
120 \\
5.3 \\
\\
13(16) \\
54 \\
\\
13 \\
45 \\
1.4 \\
700 \\
420\end{array}$ & $\begin{array}{c}25.1 \\
32-37 * \\
270 \\
420 \\
2.4 \\
\\
8.5 \\
130\end{array}$ & $\begin{array}{c}0.7 \\
\\
15.6 \\
- \\
150(230) \\
2.9 \\
4.5(7.5)\end{array}$ & $\begin{array}{c}10.15 \\
300\end{array}$ \\
\hline
\end{tabular}




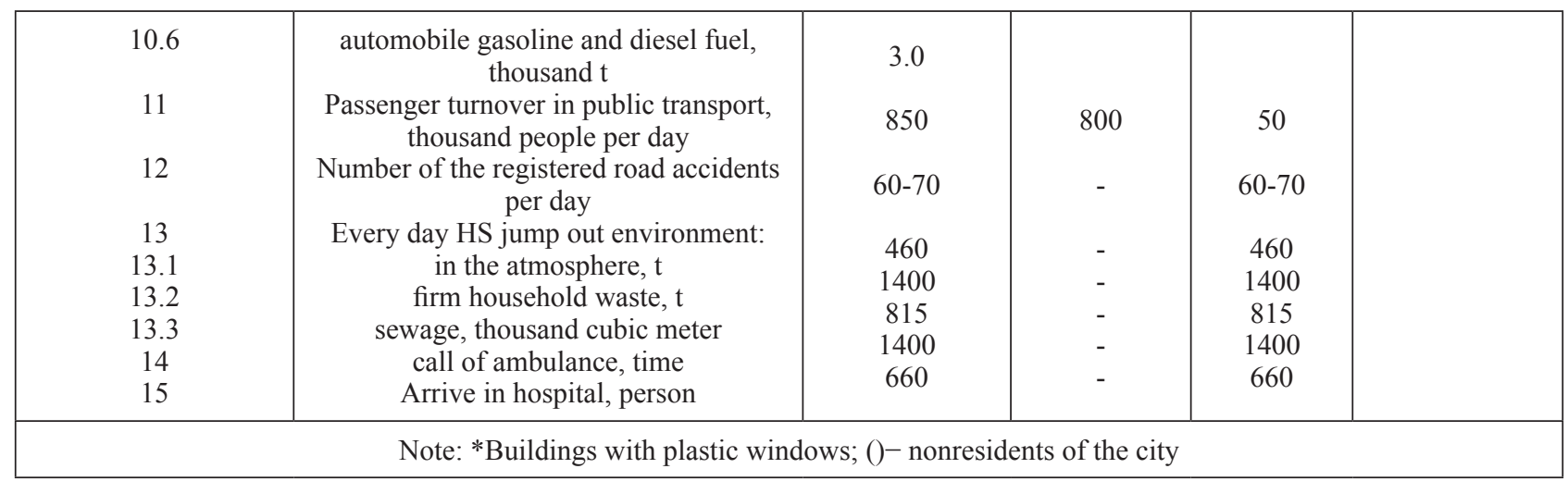

From this model we can see that Almaty does not give anything useful to environment; on the contrary, it takes everything and thus pollutes environment in huge scales - Table4:

Table 4 - Ecological model of Almaty, Thousand units per day

\begin{tabular}{|c|c|c|c|c|}
\hline № & Component or resource name & $\begin{array}{c}\text { Consumption by } \\
\text { the city }\end{array}$ & Made in the city & $\begin{array}{r}(-) \\
\text { deficiency } \\
(+) \text { excess }\end{array}$ \\
\hline 1 & Consumption of oxygen of the air pool $(\mathrm{t})$, including: & 115 & 0.7 & -114.3 \\
\hline $\begin{array}{l}1.1 \\
1.2 \\
1.3\end{array}$ & $\begin{array}{c}\text { inhabitants and visitors } \\
\text { motor transport } \\
\text { Combined heat and power plant, industrial enterprises }\end{array}$ & $\begin{array}{c}7.0 \\
10.0 \\
98\end{array}$ & & \\
\hline $\begin{array}{c}2 \\
2.1\end{array}$ & $\begin{array}{l}\text { Water use (cubic meters), incl.: } \\
\text { for economic and drinking needs of the population }\end{array}$ & $\begin{array}{c}700 \\
400-450\end{array}$ & & -700 \\
\hline 3 & Consumption of conditional foodstuff $(\mathrm{t})$, incl.: & 3.84 & & -3.84 \\
\hline $\begin{array}{c}3.1 \\
4 \\
4.1 \\
5 \\
5.1 \\
5.2 \\
5.3\end{array}$ & $\begin{array}{c}\text { Bread } \\
\text { Consumption of conditional fuel (t) } \\
\text { For motor transport } \\
\text { HS emissions in environment }(\mathrm{t}) \\
\text { In atmosphere } \\
\text { superficial sewage } \\
\text { firm household waste }\end{array}$ & $\begin{array}{c}0.42 \\
37 \\
3\end{array}$ & $\begin{array}{c}816.86 \\
0.72 \\
815 \\
1.4\end{array}$ & $\begin{array}{r}-37 \\
+816.86\end{array}$ \\
\hline
\end{tabular}

For an evident ecological assessment of influence of the city we will enter an equivalent in the form of the earth area. For example, for compensation of deficiency of 114.3 thousand oxygen it is necessary to plant the wood with the area of 823 thousand hectares, and for receiving 3.84 thousand $t$. of conditional foodstuff it is necessary in an equivalent on wheat 700 thousand hectares of the earth without work of producers - agricultural workers and workers for preparation of food to a final stage. It is similarly possible to execute the same calculations for water, completion of other types of the resources consumed by the city. The same is with raw materials for the industry and the enterprises of construction materials. Besides there is lack of territory for dispersion of emissions of harmful substances (HS) in the atmosphere, the air pool and storages of a firm waste. Thus, recognized that impurity of Almaty exceeds on the average 2-3 times of maximum-permissible concentration (maximum concentration limit).

Summarizing the areas of the territory of the earth and a surface of mirrors of water fund on each indicator received nearly 3,0 million hectares of the earth necessary for independent functioning 
of Almaty, and it is 94 times more than the present territory of the Kazakhstan megalopolis.

The city of Almaty is the largest urbanized center of Kazakhstan. However, development and city industrialization without the sufficient accounting of physical, geographical and climatic features and ecological requirements led to ecological disruption in the megalopolis territory.

Average air temperature of Almaty $+8,9{ }^{\circ} \mathrm{C}$ (during the warm period $+28,2^{\circ} \mathrm{C}$, the cold period- 11 ${ }^{0} \mathrm{C}$ ), barometric pressure $920 \mathrm{gPa}$, the prevailing direction of a wind - southern. Settlement geographic latitude is $44^{\circ} \mathrm{NL}$. The northern point of Almaty has a mark of $670 \mathrm{~m}$ above sea level, and southern $970 \mathrm{~m}$.

In Almaty, climatic factors create conditions for formation of high pollution of the atmosphere of the city. The city is characterized as light wind, repeatability of light breezes (to $1 \mathrm{M} / \mathrm{sec}$ ) it is estimated in the summer here at $71 \%$, in the winter in $79 \%$, in a type of it mid-annual value of speed of a wind in the city doesn't exceed $1,7 \mathrm{M} / \mathrm{sec}$ which was confirmed by us experimental data.

The analysis of orographical conditions of the territory of the megalopolis shows that its vicinities are open in the northern direction on hundreds kilometers, and in the southern - surround stretching ridges, and it promotes penetration of air masses into a foothill part where powerful air temperature inversions are formed, especially in the winter.
Accumulation of harmful impurity in a ground layer of air is promoted by light breezes, and temperature inversions, which are an obstacle for development of vertical air exchange and diffusion of polluting substances in the atmosphere.

At all directions of a wind, the city appears in so-called «an aerodynamic shadow». Climatic features create adverse conditions for dispersion of emissions; especially exhaust gases of motor transport and individual sources of heating. The exhaust gases containing oxides of carbon, nitrogen, hydrocarbons, firm particles and compounds of lead collect in a ground layer of the atmosphere. The most part from them settles on an asphalt covering and a soil cover. The dust with a complex of metals and other polluting substances through respiratory organs and skin gets to a human body.

Results and Discussion. According to the generalized data on the average in a year across Almaty and its vicinities it is observed anti-cyclones of $10 \%$, cyclones of $6 \%$, baric (MGB) formations of $22 \%$, crests of $32 \%$, hollows of $18 \%$, wave indignations of $12 \%$.

In drawing 1 wind roses on characteristic for winter (A-January) and summer (B-July) are presented to months, an annual course (C-year), constructed according to the data presented in tabl 5.

Drawing 1 - Repetition (\%) of the directions of a wind and calms (in the circle center) at different times of the year, for 2011.

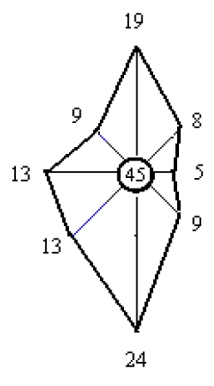

A - january

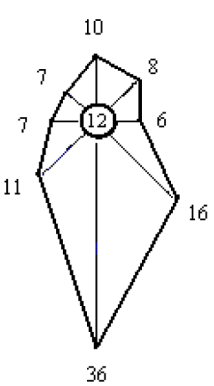

B - july

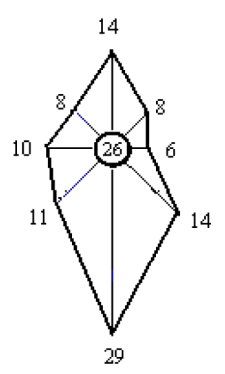

C - year
In the center of each wind rose repeatability of calms from total number of cases, as a percentage is shown. Strengthening of a wind is observed in summer months easing it to calm values in the winter (drawing 1). In a winter season baric gradients are a little underestimated at the expense of aerographical anti-cycle genesis, a stagnation coming from the North of mass of air and development along mountains of winter inversions which give stability to ground layers of the atmosphere. The summer maximum of speed of a wind is caused by aerographical strengthening of cyclonic processes and activating mountain valley circulation - Table 5: 
Table 5 - Repetition of the directions of a wind and calms (\%) Almaty, 2016

\begin{tabular}{|c|c|c|c|c|c|c|c|c|c|}
\hline Month & N & NE & E & SE & S & SW & W & SW & Calm \\
\hline January & 19 & 8 & 5 & 9 & 24 & 13 & 13 & 9 & 45 \\
\hline February & 18 & 9 & 5 & 9 & 20 & 11 & 15 & 13 & 43 \\
\hline March & 16 & 10 & 7 & 9 & 22 & 11 & 14 & 11 & 29 \\
\hline April & 14 & 10 & 6 & 13 & 27 & 9 & 12 & 9 & 19 \\
\hline May & 12 & 8 & 6 & 14 & 32 & 11 & 10 & 7 & 17 \\
\hline June & 12 & 7 & 6 & 15 & 35 & 10 & 8 & 7 & 13 \\
\hline July & 10 & 8 & 6 & 16 & 36 & 11 & 7 & 6 & 12 \\
\hline August & 12 & 8 & 6 & 16 & 35 & 10 & 7 & 6 & 12 \\
\hline September & 14 & 7 & 6 & 18 & 33 & 8 & 7 & 7 & 14 \\
\hline October & 14 & 8 & 6 & 19 & 30 & 8 & 8 & 7 & 25 \\
\hline November & 13 & 8 & 6 & 15 & 29 & 11 & 13 & 18 & 34 \\
\hline December & 15 & 7 & 6 & 12 & 24 & 14 & 13 & 9 & 43 \\
\hline Year & 14 & 8 & 6 & 14 & 29 & 11 & 10 & 8 & 26 \\
\hline
\end{tabular}

The function of passing of flat winds the system should be fulfilled by avenues, boulevards, recreation areas of the wide orientation main element of which is the recreational zone along the LAC (Large Almaty Channel), and also the highways which are cutting through on a meridian of Almaty, since the party of mountains should carry out function of corridors. However, this ecologically justifiable principle is broken in the last decade because of rash construction of buildings and constructions across the direction of a wind stream both from the South, and from the North. All these led to creation of the man-made ditch surrounded with the ridge and a technogenic wall in the form of high-rise constructions of the industrial enterprises and multistoried buildings.

Basis of formation of perspective planning structure of the city is the natural and ecological and transport framework. The natural and ecological framework is formed by the mountain rivers proceeding in the meridional direction through the city, parks, squares, boulevards and other planted trees and shrubs territories which are city «lungs». As a whole the structure of an ecological framework, is the large meshed grid, consisting their mutually being crossed green corridors of meridian and wide orientation for the admission of air streams mountain valley and flat circulation.

The following element of the urbanized framework of the city is the system of transport highways. The master plan provides development and improvement of transport structure of the city by creation in additions to existing new meridian and wide highways, roundabout highways, a network of service of vehicles, construction of traffic intersections, overpasses, platforms etc. The principle of creation of uniform system of high-speed city roads and highways is put in a basis of development of a street road network with differentiation of the last on highways of continuous and adjustable movement.

In Almaty according to various data and taking into account building, there are attached areas of 1260-1300 streets with total length of 1700-1800 $\mathrm{km}$ and extent of roads with a firm covering of $1600 \mathrm{~km}$.

Conclusion. Designed ecological-economic model of modern large city on the example of Almaty, based on the main provisions of statistical theory, theories of logistics and the similarity of the General plan of development of Kazakhstan megapolis, the Strategy of transport development of Kazakhstan, programs to reduce the traffic load on the highways regulations of international and national importance, as well as on the basis of predictive decisions arising from the comprehensive consideration of the issues City transport road ecology (CTRE). It includes for the first time scientifically grounded ecological and economic indicators and daily ecological model of Almaty which were initial data for further researches and calculations. 


\section{References}

Helbing D. (2001) Traffic and related self-driven many-particle systems, Rev. Mod. Phys., v. 73, 1067.

Rozenberg G.S., Shitikov V.K., Brusilovskii P.M. (1994) Ecologicheskoe prognozirovanie [Environmental forecasting] (Functionalnie predictor vremennih riadov). - Togliatti,. $-182 \mathrm{p}$.

Kuhne R., Mahnke R., Lubashevsky I., and Kaupus J. (2002) “Probabilistic description of traffic breakdowns” Phys. Rev. E v. 65 , 066125

Kerner B. S. (2004) Physics of Traffic (Springer, Berlin).

Krug J., Spohn H. //Phys. Rev. A. - Vol. 83. - P. 4271.

Lubashevsky I., Wagner P., Mahnke R. (2003) "Rational-driver approximation in car-following theory” Phys. Rev. E v. 68, 056109 Lubashevsky I., Wagner P., Mahnke R. (2003), "Bounded rational driver models”, Eur. Phys. J. B v. 32, 243-247.

Lubashevsky I., Mahnke R., Wagner P., and Kalenkov S. (2002) "Long-lived states in synchronized traffic flow: Empirical prompt and dynamical trap model" Phys. Rev. E v.66, 016117

Lubashevsky I., Hajimahmoodzadeh M., Katsnelson A., and Wagner P. (2003) Noised-induced phase transition in an oscillatory system with dynamical traps, Eur. Phys. J. B v.36, 115

Ligthill M.J., Whitham F.R.S. (1995) On kinetic waves II. A theory of traffic flow on crowded roads //Proc. of the Royal Society Ser. A. - Vol. 229. - No. 1178. - P. 317-345.

Shvecov V.I. (2003) Matematicheskoe modelirovanie transportnih potokov [Mathematical modeling of transport flows] //Avtomatika i telemehanika. № 11. - P. 3.

Studying the ebb and flow of stop-and-go; Los Alamos Lab using cold war tools to scrutinize traffic patterns alan sipress washington post staff writer (1999) Thursday, August 5, Site: www.science.com.

Treiterer J., Myers J.A., (1974) The hysteresis phenomenon in traffic flow / In D.J. Buckley, editor, Proc. 6th ISTT, p. 13, Artarmon, New South Wales.

Wagner P., Lubashevsky I., "Empirical basis for car-following theory development", e-print Arxiv:cond-mat/0311192.

Yedilbayev B., Shokanova A. (2013) The Student-centered and practice-oriented approaches in the system of preparing ecologists World Applied Sciences Journal 25 (5): pp.699-703.-Pakistan 